University of Nebraska - Lincoln

DigitalCommons@University of Nebraska - Lincoln

H. W. Manter Laboratory Library Materials

9-1916

\title{
On the Anatomy and Relationships of Some North American Trematodes
}

Horace Wesley Stunkard

University of Illinois

Follow this and additional works at: https://digitalcommons.unl.edu/manterlibrary

Part of the Parasitology Commons

Stunkard, Horace Wesley, "On the Anatomy and Relationships of Some North American Trematodes" (1916). H. W. Manter Laboratory Library Materials. 13.

https://digitalcommons.unl.edu/manterlibrary/13

This Article is brought to you for free and open access by DigitalCommons@University of Nebraska - Lincoln. It has been accepted for inclusion in H. W. Manter Laboratory Library Materials by an authorized administrator of DigitalCommons@University of Nebraska - Lincoln. 


\section{ON THE ANATOMY AND RELATIONSHIPS OF SOME NORTH AMERICAN TREMATODES *}

\section{Horace W. Stunkard}

As the result of an extended study of three families of North American trematodes, Polystomidae, Aspidogastridae and Paramphistomidae, certain points of interest in regard to the structure and classification have been elucidated. Since the publication of the completed work may be delayed, a brief statement of the more important points is presented here in advance of the appearance of the extended paper.

In the latest classification of the monogenetic trematodes, or Heterocotylea as they were termed by Monticelli, Odhner (1912) divided the group into two suborders, Monopisthocotylea in which a "true vagina is present," and Polyopisthocotylea in which a true vagina is wanting and the so-called "ductus vaginalis" is present. After careful study of the female ducts in the Polystomidae, I am able to show that the organ which functions as a vagina is homologous in all monogenetic trematodes and that there can be no division of the group on the basis of differences in this structure. In the complete paper the full evidence is submitted to show that the "true vagina" of the Monopisthocotylea is homologous to the originally single, secondarily paired and subsequently fused vaginae of the Polyopisthocotylea; altho the two suborders of Odhner are nevertheless valid, the essential difference between them is that the genito-intestinal canal is lacking in the former and present in the latter group.

The species that have been included in the genus Polystoma show a wider range of structural variation than is usually present in a natural genus. There are marked differences in the character of digestive and reproductive systems and variation exists also in the type of adhesive apparatus. In $P$. integerrimum the ceca are much branched, ramifying thru the body and caudal disc. In $P$. alluaudi the ceca occupy the same location but are merely lobed and have no secondary branches. In P. bulliense, according to Johnston (1912), "a diverticulum from the buccal cavity runs backwards, ventral to the pharynx, and for a distance equal to its length forming a median unpaired buccal pocket." In all other known species there is a simple bifurcate intestine, the ceca terminating just anterior to the caudal disc. In two specimens of $P$. hassalli, however, the ceca are connected posteriorly.

* Contributions from the Zoological Laboratory of the University of Illinois under the Direction of Henry B. Ward, No. 72. 
The testis is a much branched structure in $P$. kachugae, in $P$. integerrimum it is lobed, and in the other known species it is oval or spherical. In $P$. integerrimum and $P$. bulliense the lateral vaginal swellings are formed by a large number of papillae which are perforated by fine canals, and in all other known species the vaginae are large open funnèls and the lateral swellings are reduced or absent. In $P$. integerrimum, $P$. bulliense and $P$. alluaudi there is a long uterus which forms many loops in the intra-cecal area and contains a large number of eggs. In all other known forms, the uterus is situated at the level of the ovary on the opposite side of the body and contains a single large egg or embryo.

The caudal disc bears on its ventral face the chief organs of attachment. These consist of suckers and hooks, the former arranged in pairs, three suckers on either side of the median line. In all previously reported forms except $P$. alluaudi. the anterior suckers are separated by considerable distance giving the disc the shape described by Leidy as cordiform. In the single specimen of $P$. alluaudi described by Beauchamp, both the caudal and cephalic suckers are separated while those of each side are contiguous. In $P$. orbiculare n. sp. each sucker of the disc is separated from the two adjacent to it by uniform distances, making a perfect circle of bothria. In six species studied by the writer these suckers are complicated structures set more or less deeply in the parenchyma of the caudal disc. Their structure, character of insertion and muscular attachments are described in the complete paper. The caudal disc typically bears eighteen hooks. The larval hooks are anchor shaped and are situated six in a row between the anterior suckers, one inside each sucker at the base, and two or four between the posterior suckers. Between the posterior suckers there is also a pair of great hooks several times the size of the larval hooks, and in species in which a single pair of larval hooks is present, there is a third pair of hooks similar in shape to the great hooks and intermediate in size between the great and larval hooks.

In $P$. orbiculare n. sp. neither pair of the great hooks are present, and in $P$. opacum $n$. sp. there is a single pair of great hooks, very small and poorly developed.

The present study of the polystomes has emphasized the morphological variation and wide geographic distribution represented by the genus. This may mean either that the group is very old and has been subjected to conditions producing wide variation, or that it really lacks generic entity and consists of various heterocotylean forms which have specialized in the direction of an endoparasitic habit and that the morphological resemblance is cenogenetic.

Four new species are added to the genus Polystoma, as follows: 
POLYSTOMA ORBICULARE nov, spec.

Length 2.7 to $3.75 \mathrm{~mm}$; width 0.9 to $1.2 \mathrm{~mm}$. Caudal disc circular, 0.8 to $1.07 \mathrm{~mm}$. in diameter, bothria arranged symmetrically in a circle. Only hooks present on disc are larval hooks in bases of suckers. Anterior sucker 0.25 to $0.27 \mathrm{~mm}$. in length, 0.37 to $0.42 \mathrm{~mm}$. in width; pharynx spherical 0.24 to $0.28 \mathrm{~mm}$. in diameter; esophagus short. Testis spherical or oval, 0.36 to $0.5 \mathrm{~mm}$. in length, 0.29 to $0.39 \mathrm{~mm}$. in width, near or slightly anterior to middle of body. Genital coronet of 16 hooks equal in length. Ovary lateral, on either side of body, comma-shaped, 0.1 to $0.14 \mathrm{~mm}$. wide by 0.14 to $0.185 \mathrm{~mm}$. long. Vitellaria occupy dorsal and lateral areas from pharynx to caudal disc except in region dorsal to germ glands where they are reduced or absent.

In the urinary bladder of Pseudemys scripta from Raleigh, N. C., and of Chrysemys marginata from Chicago, Illinois, and Creston, Iowa.

POLySTOMA OPACUM nov. spec.

Length 3.25 to $4 \mathrm{~mm}$; width 0.8 to $1 \mathrm{~mm}$. Anterior sucker 0.2 to $0.22 \mathrm{~mm}$. long, $0.23 \mathrm{~mm}$. wide; pharynx spherical, $0.3 \mathrm{~mm}$. in diameter; esophagus short. Testis spherical or oval, 0.4 to $0.5 \mathrm{~mm}$. in diameter, slightly anterior to middle of body. Genital coronet of 32 similar hooks. Ovary lateral, comma-shaped or ovoid, 0.16 to $0.2 \mathrm{~mm}$. long, 0.08 to $0.12 \mathrm{~mm}$. wide. Vitellaria strongly developed, extend from pharynx to caudal disc, occupying lateral and dorsal regions of body except area over testis, ovary and uterus.

In esophagus of Trionyx ferox and Malacoclemmys leseurii from Newton, Texas.

POLYSTOMA MEgACOTYLE nov, spec,

Length 2.5 to $2.7 \mathrm{~mm}$.; width 0.71 to $0.78 \mathrm{~mm}$. Caudal disc cordiform; bothria large, overlap. Anterior sucker $0.28 \mathrm{~mm}$. long, 0.35 to $0.42 \mathrm{~mm}$. wide; pharynx 0.35 to $38 \mathrm{~mm}$. long, 0.38 to $0.44 \mathrm{~mm}$. wide. Testis near middle of body, 0.28 to $0.33 \mathrm{~mm}$. long, 0.33 to $38 \mathrm{~mm}$. wide. Genital coronet contains 36 hooks in one and 42 in another mounted specimen. Ovary broad comma-shaped organ on either side of median line, $0.1 \mathrm{~mm}$. long, $0.075 \mathrm{~mm}$. wide. Vitellaria extend in lateral and dorsal areas of body from pharynx to caudal disc, reduced or absent in small field dorsal to germ glands.

From oral cavity of Chrysemys marginata, Creston, Iowa.

POLYSTOMA MICROCOTYLE nov. spec.

Length $3 \mathrm{~mm}$; width $0.78 \mathrm{~mm}$. Caudal disc cordiform; bothria small, separated. Anterior sucker $0.2 \mathrm{~mm}$. long, $0.42 \mathrm{~mm}$. wide; pharynx $0.37 \mathrm{~mm}$. long, $0.4 \mathrm{~mm}$. wide. Testis slightly anterior to 
middle of body, $0.36 \mathrm{~mm}$. long, $0.42 \mathrm{~mm}$. wide. Genital coronet of 32 hooks, equal in length. Ovary lateral, $0.075 \mathrm{~mm}$. long, $0.1 \mathrm{~mm}$. wide. Vitellaria well developed, same extent as in $P$. megacotyle.

From oral cavity of Chrysemys marginata, Creston, Iowa.

In the family Aspidogastridae the three North American species have been restudied. A detailed comparison of specimens of Aspidogaster conchicola with the descriptions of Voeltzkow (1888), Stafford (1896), and other writers confirms former observations and substantiates the statements of Leidy (1851) and subsequent authors that $A$. conchicola occurs in this country. The examination of specimens of Cotylaspis insignis and Colylaspis cokeri corrects and supplements former descriptions. Nickerson's (1902) classification of the family is revised and brought to date.

Representatives of three species of paramphistomes have furnished the basis for studies on that family. Two species are from North American turtles and the third is from a duck, Anas platyrhynchos. An examination of the literature showed that these forms could not be included in any previously described genera.

A new genus Alassostoma is created to contain the two species from turtles. The genus is characterized by the presence of large oral evaginations which open separately from the oral sucker, an esophageal bulb composed of concentric muscle lamellae, germ glands situated near the middle of the body in the median line, both testes anterior to the ovary, vitellaria consisting of small scattered follicles in the lateral and posteriorly in the median area of the body; Laurer's canal opens in the mid-dorsal line, anterior to the opening of the excretory vesicle; cirrus sac and uterus open to the exterior thru a common hermaphroditic duct. Alassostoma magnum n. sp. is taken as type of the genus in which is included also Alassostoma parvum n. sp.

The genus Alassostoma has the type of lymph and excretory systems present in the genus Schizamphistoma and designated by Looss (1912) as characters of the subfamily to which that genus belongs. Looss predicted that with the discovery of other genera it would be necessary to create a new subfamily to contain them, and at that time stated the subfamily characters. With the discovery of a second genus so similar to Schizamphistoma, the formal erection of the new subfamily is necessary. Schizamphistoma Looss was designated as the type genus and the name of the subfamily becomes Schizamphistominae. The distinguishing characters of the subfamily are stated by Looss to be two long excretory vesicles which extend singly to the anterior end of the body and a lymph system composed of three canals on either side of the body which extend longitudinally and 
break up into many sinuses in the region of the suckers. The subfamily contains the genera Schizamphistoma, including also $S$. spinulosum which as indicated by Looss should probably be made the type of a new genus, and the genus Alassostoma.

Alassostoma magnum agrees with Schizamphistoma scleroporum in general appearance and size, in type of excretory and lymph systems, in character of vitellaria, and in general type of reproductive and alimentary organs; but $A$. magnum has large oral evaginations, which pockets are reduced and do not extend outside the sucker in $S$. scleroporum; further $A$. magnum lacks the preoral sphincter which is present in $S$. scleroporum. In $A$. magnum the uterus and cirrus sac open to the surface thru a common hermaphroditic duct; in $S$. scleroporum they open separately. In $A$. magnum the testes are further porteriad and the ovary is situated one fourth to one third of the body length from the posterior end instead of at the level of the anterior margin of the acetabulum as is the case in $S$. scleroporum. In the latter species the testes and ovary are widely separated whereas in $A$. magnum they are relatively close together. $A$. magnum agrees with $S$. spinulosum in the presence of oral evaginations and lack of preoral sphincter, but differs from it in the manner of coiling of the excretory vesicles, in the presence of common hermaphroditic duct, in the character of the vitellaria, as well as in relative positions of the testes and ovary. These morphological data show differences too fundamental to permit the inclusion of $A$. magnum in the same genus with either $S$. scleroporium or $S$. spinulosum.

Alassostoma parvum agrees with $A$. magnum in general morphological features, presence of oral evaginations, lack of preoral sphincter, type of lymph and excretory systems, in character of genital organs and ducts, also in relative position of testes and ovary. $A$. parvum therefore agrees with and differs from $S$. scleroporum and $S$. spinulosum in the same manner as $\mathrm{A}$. magnum. That the two American forms are not different developmental stages of the same species is shown by the great difference in size of the worms and relative differences in size of suckers and genital organs. One mounted specimen of $A$. magnum $10 \mathrm{~mm}$. long is not sexually mature while none of the individuals of $A$. parvum are more than $3 \mathrm{~mm}$. in length. $A$. magnum is large with small suckers, whereas $A$. parvum is small with relatively large suckers; and this feature suggested the name Alassostoma.

Alassostoma magnum was collected from the large intestine of Pseudemys troosti and $P$. elegans from Havana, Illinois, and from $P$. clegans from Chicago, Ill. The specimens of $A$. parvum were found in the cloaca of Chelydra serpentina at Urbana, Ill. 
The paraniphistomes from Anas platyrhynchos were collected in Rock County, Nebraska. Unfortunately the fixation of the parasites is such that the excretory and lymph systems can not be traced, altho remnants of both appear in sections. This species closely resembles Amphistoma lunatum Diesing. Both are parasites of American ducks, and are the only paramphistomes at present known from avian hosts. They are nearly equal in size, are similar in shape, have a subterminal oral sucker, reproductive and digestive systems that compare closely, and acetabula of the same form, consisting of an anterior portion and a posterior overhanging lip which terminates on either side in a small cone-like projection. The species at hand differs from $A$. lunatum in its smaller oral evaginations, shorter esophagus, and in having oval, lobed testes and ovary instead of spherical germ glands. The acetabu-. lum is nearer the ovary and the vitellaria are entirely extracecal while in $A$. lunatum they extend between the ceca.

Amphistoma lunatum has been placed as an appendix to every classification of the paramphistomes that has ever been attempted. With the discovery of a form so similar that the two must belong together, a new genus is proposed to contain the two species. The peculiar divided condition of the acetabulum suggested the name Zygocotyle for the genus. The species at hand, for which I propose the name $Z y$ gocotyle ceratosa, is designated as type and in the genus is included also the species $Z$. lunatum (Diesing). As diagnostic characters of the genus may be mentioned the subterminal oral sucker, posterior sucker divided or provided with a caudal overhanging lip, absence of cirrus sac, and separate openings for male and female ducts. Others will undoubtedly appear when the-character of the excretory and lymph vessels are known. The genus $Z$ ygocotyle differs from all other known genera of the Paramphistomidae in the ventral position of the oral sucker and the peculiar character of the acetabulum. None of the existing subfamilies will include it fairly, but since the present classification of the Paramphistomidae is somewhat uncertain and the structure of the lymph and excretory systems of this genus is as yet unknown, no further attempt at classification of the group is made at this time.

Types of all the new species described in this paper have been deposited in the Helminthological Collection of the University of Illinois.

\section{SUMMARY}

Extended study of North American representatives of the three trematode families, Polystomidae, Aspidogastridae and Paramphistomidae has made possible the first comprehensive treatment in this 
country of their structure and classification. Four new species are added to the genus Polystoma and three new species of two new genera are added to the Paramphistomidae.

\section{Literature Cited}

Johnston, S. J. 1912. On Some Trematode Parasites of Australian Frogs. Proc. Linn. Soc. N. S. Wales, 37: 285-3k2, pl. 14-43.

Leidy, J. 1851. Helminthological Contributions II. Proc. Acad. Nat. Sci. Phila., 5: 224-227.

Looss, A. 1912. Ueber den Bau einiger auscheinend seltener TrematodenArten. Zool. Jahrb., Suppl., $15: 323-366,3$ pl.

Nickerson. W. S. 1902. Cotylogaster occidentalis n. sp. and a Revision of the Family Aspidobothridae. Zool. Jahrb., Syst., 15:597-624, 2 pl.

Odhner, T. 1912. Bemerkungen zum natürlichen System der Monogenen Trematoden. Zool. Anz., 39: 337-351.

1913. Noch einmal die Homologien der weiblichen Genitalwege der monogenen Trematoden. Zool. Anz., 41 : 558-559.

Stafford, J. 1896. Anatomical Structure of Aspidogaster conchicola. Zool. Jahrb., Anat., 9:477-542, 4 pl.

Voeltzkow, A. 1888. Aspidogaster conchicola. Arb. zool--zoot. Inst. Würzb., $8: 249-292,5 \mathrm{pl}$. 